\title{
Behavior of broilers subjected to different light spectra and illuminances
}

\author{
Aline C. Lucena ${ }^{1}$, Héliton Pandorfi ${ }^{2}$, Gledson L. P. Almeida ${ }^{2}$, Cristiane Guiselini² ${ }^{2}$ José E. M. Araújo $^{1} \&$ \\ Tatiana P. N. da S. Rodrigues ${ }^{1}$ \\ ${ }^{1}$ Universidade Federal Rural de Pernambuco/Programa de Pós-Graduação em Engenharia Agrícola, Recife, PE, Brasil. E-mail: alinelucena19@gmail.com - \\ ORCID: 0000-0003-1990-6980; eduardo_ta2005@hotmail.com - ORCID:0000-0002-8415-5186; tatianapnsilva@hotmail.com - ORCID: 0000-0003-4435-1112 \\ ${ }^{2}$ Universidade Federal Rural de Pernambuco/Departamento de Engenharia Agrícola, Recife, PE, Brasil. E-mail: hpandorf@hotmail.com (Corresponding \\ author) - ORCID: 0000-0002-2037-8639; gledson81@hotmail.com - ORCID: 0000-0002-5813-4517; cguiseli@hotmail.com - ORCID: 0000-0003-2909-9502
}

\begin{abstract}
The ideal illuminance in poultry houses for broiler chickens may lead to improvement in housing efficiency and broiler welfare. In this context, the objective of this research was to evaluate the behavior and welfare of broiler chickens under effect of illuminance by light-emitting diode (LED) in white band (400$760 \mathrm{~nm})$ and blue/green band (470-525 nm). The experiment was conducted from October to December 2017, in the municipality of Carpina, PE, Brazil, and had 384-oneday-old chicks (mixed batch), Cobb 500 strain. The adopted design was completely randomized, in a $4 \times 2$ factorial scheme, corresponding to four illuminances, $5 \mathrm{~lx}$ (I1), $20 \mathrm{~lx}$ (I2), $150 \mathrm{~lx}$ (I3) and 5-20 lx (5 lx in the $1^{\text {st }}, 2^{\text {nd }}$ and $6^{\text {th }}$ weeks and $20 \mathrm{~lx}$ in the $3^{\text {rd }}$, $4^{\text {th }}$ and $5^{\text {th }}$ weeks - I4), and two light spectra using LED bars, RGB type, in white (400-760 nm) color (C1) and blue/green (470-525 nm) dichromatic color (C2), with three repetitions. A continuous lighting program was used, $18 \mathrm{~h}$ of light and $6 \mathrm{~h}$ of dark per day. Ingestive, posture, comfort and natural behaviors, aggressiveness and discomfort of the broiler were evaluated. Broiler behavioral variables were determined by the frequency of the events and their probability of occurrence by the Chi-square test. Broilers subjected to wavelengths in the blue/green range and illuminance of $20 \mathrm{~lx}$ and 5-20 lx showed more significant ingestive and comfort behaviors, which demonstrates better welfare under these housing conditions.
\end{abstract}

Key words: poultry, animal welfare, artificial lighting

\section{Comportamento de frangos de corte submetidos a diferentes espectros luminosos e iluminâncias}

RESUMO: A iluminância ideal em aviários para frangos de corte pode levar à melhoria da eficiência do ambiente de alojamento e no bem-estar das aves. Neste contexto, objetivou-se avaliar o comportamento e o bem-estar de frangos de corte sob efeito da iluminância por lâmpadas de diodo emissor de luz na faixa do branco $(400-760 \mathrm{~nm})$ e azul/verde $(470-525 \mathrm{~nm})$. O experimento foi conduzido de outubro a dezembro de 2017, no município de Carpina, PE, e contou com 384 pintos de um dia (lote misto), linhagem Cobb 500. O delineamento adotado foi inteiramente casualizado, em esquema fatorial $4 \times 2$, correspondendo a quatro iluminâncias, 5 lx (I1), 20 lx (I2), 150 lx (I3) e 5-20 lx (5 lx na 1 $1^{\mathrm{a}}, 2^{\mathrm{a}}$ e $6^{\mathrm{a}}$ semana e $20 \mathrm{~lx}$ na $3^{\mathrm{a}}$, $4^{\mathrm{a}}$ e $5^{\mathrm{a}}$ semana - I4), e dois espectrons luminosos com a utilização de lâmpadas de diodo emissor de luz (LED), tipo bastão RGB (400-760 nm) branco (C1) e dicromático (470-525 nm) azul/verde (C2), com três repetições. Utilizou-se programa de iluminação contínuo, $18 \mathrm{~h}$ de luz e $6 \mathrm{~h}$ de escuro por dia. Foram avaliados os comportamentos ingestivos, postura, conforto e natural, agressividade e desconforto das aves. As variáveis comportamentais das aves foram determinadas pela frequência dos eventos e sua probabilidade de ocorrência pelo teste Quiquadrado. As aves submetidas aos comprimentos de onda na faixa do azul/verde e iluminância de 20 lx e 5-20 lx, apresentaram comportamentos ingestivos e de conforto mais expressivos, o que evidencia melhor bem-estar nestas condições de alojamento.

Palavras-chave: avicultura, bem-estar animal, iluminação artificial 


\section{INTRODUCTION}

Broiler strains have fast growth and high genetic potential, but adequate conditions should be provided for birds to express this potential and achieve satisfactory productive performance (Vercellino et al., 2013).

Behavior manifestation frequency can be influenced by the characteristics and conditions of housing, and light stimuli such as illuminance, wavelength and lighting program are abiotic factors that affect the physiological development, behavioral responses and welfare of poultry (Parvin et al., 2014).

There are several natural behaviors (foraging, pecking objects, exploring feathers) that indicate welfare, as well as undesirable behaviors (aggressiveness). The correct interpretation of behavioral expression includes the frequency, duration and sequence of these behaviors, interpreted as patterns or signs that can be used to infer about the welfare of broilers (Costa et al., 2012).

Illuminance plays a fundamental role in the health of broilers (Blatchford et al., 2012). Low lighting is more effective for controlling aggressive behaviors such as cannibalism (Olanrewaju et al., 2014). High light intensity can improve the activity (Rault et al., 2017), increase the growth and percentage of breast muscle (Deep et al., 2013), besides promoting the expression of comfort behaviors in broilers.

Sultana et al. (2013) point out that red and red-yellow light activate movements and fear response in broiler chicken, while blue and green/blue keep broilers calmer.

In this context, the objective of this study was to evaluate the behavior and welfare of broilers under the effect of illuminance by LED bars in the white (400-760 nm) and blue/green (470$525 \mathrm{~nm}$ ) ranges, throughout the production cycle (42 days).

\section{Material ANd Methods}

The experiment was conducted from October 27 to December 8, 2017, in the municipality of Carpina, PE, Brazil, at the Small Animal Experimental Station of Universidade Federal Rural de Pernambuco ( $7^{\circ} 51^{\prime} 02^{\prime \prime}$ S, 35 $35^{\circ} 15^{\prime} 16^{\prime \prime} \mathrm{W}$ and altitude of $186 \mathrm{~m}$ ). The climate of the region is characterized as megathermal (As), with precipitation in the winter and dry season from summer to autumn, according to Köppen's classification (Alvares et al., 2013).

The experiment was carried out in an experimental shed for poultry production, with dimensions of $9.35 \mathrm{~m}$ width by $30.40 \mathrm{~m}$ length; ceiling height of $2.84 \mathrm{~m}$, without lining; the sides of the facility have $0.25-\mathrm{m}$-high masonry wall and polyethylene screen, concrete floor and wood shaving bedding; the shed has a 2.20-m-wide central corridor; double-pitched roof, covered with 4-mm-thick fiber cement tiles, $1.5 \mathrm{~m}$ eaves and NortheastSouthwest orientation. During the experimental period, the minimum, maximum and mean air temperatures inside the shed were $23.7,33.8$ and $27.6{ }^{\circ} \mathrm{C}$, respectively; the minimum, maximum and mean values of relative humidity inside the shed were equal to 52,90 and $75 \%$, respectively.

A total of 384 one-day-old chicks (mixed batch), Cobb 500 strain, were acquired from a commercial hatchery. The birds were subjected to all recommended vaccines in the initial stage
(Marek, Gumboro, Newcastle and Bronchitis). The experiment comprised 24 pens, with an area of $2.912 \mathrm{~m}^{2}$ per pen, while each treatment had 3 pens (replicates) with 16 birds per pen.

In the containment pens, the birds were exposed to the heating source by a $150-\mathrm{W}$ electrical resistance, installed at $0.50 \mathrm{~m}$ from the floor and managed according to the distribution profile of the birds in the first two weeks of the production cycle and actuated only at night. In this phase, the curtains remained closed. Feed and water were supplied at will in specific feeders and drinkers according to the rearing stage and nutritional requirement of the birds.

The design adopted was completely randomized, in a 4 x 2 factorial scheme, corresponding to four illuminances, $5 \mathrm{~lx}$ (I1), $20 \mathrm{~lx}$ (I2), $150 \mathrm{~lx}$ (I3) and 5-20 lx (5 lx in $1^{\text {st }}, 2^{\text {nd }}$ and $6^{\text {th }}$ weeks and $20 \mathrm{~lx}$ in $3^{\text {rd }}, 4^{\text {th }}$ and $5^{\text {th }}$ weeks - I4), and two light spectra using light-emitting diode (LED) bars, RGB type, in white (400-760 nm) color (C1) and blue/green (470-525 nm) dichromatic color (C2), with three repetitions. A continuous lighting program was used, with $18 \mathrm{~h}$ of light ( $12 \mathrm{~h}$ of natural lighting and $6 \mathrm{~h}$ of artificial lighting) and $6 \mathrm{~h}$ of dark a day (18L:6D), actuated by a TMAØBC analog timer, from $23 \mathrm{~h} 30 \mathrm{~min}$ to $05 \mathrm{~h} 30 \mathrm{~min}$, when the lighting system was turned off.

The LED bars were coupled to a PVC tube fixed longitudinally on the sides and/or in the center of the pens at $0.60 \mathrm{~m}$ height from the floor, for illuminance of $150 \mathrm{~lx}$, and at $0.80 \mathrm{~m}$ height from the floor in the other treatments, in order to maintain the best illuminance distribution grid inside the pens.

The distance between LED bars was defined according to the desired illuminance, as well as the amount of tubes, using one LED bar for white and blue/green colors with $5 \mathrm{~lx}$ illuminance; one for white and blue/green colors with $20 \mathrm{~lx}$ illuminance; six for white color with $150 \mathrm{~lx}$ illuminance and seven tubes for blue/green color with $150 \mathrm{~lx}$ illuminance. To avoid the influence of the different light spectra and illuminances on the adjacent pen, black plastic tarpaulins were used next to the polyethylene screen.

Broiler behavior was monitored by eight VMD S3020 IR color cameras, with infrared and $3.6 \mathrm{~mm}$ lens, divided above each experimental pen, with wireless transmission to a notebook, where the videos were stored and then visually analyzed using Intelbras iSIC 6 software.

Broiler behavior was evaluated by analyzing digital images at continuous time intervals of $10 \mathrm{~min}$, every hour of the day, in a total of $240 \mathrm{~min}$ a day for each experimental treatment, according to the methodology proposed by Schiassi et al. (2015). Access to the feeder, access to the drinker and the expression of comfort and natural behavior were evaluated during the actuation of artificial lighting.

The birds were identified with gentian violet on the head, back and wings to facilitate visualization by the observer. Five birds were evaluated per treatment, enabling the monitoring of 40 birds.

Behavioral reactions were quantified with emphasis on the characterization of animal welfare, according to an ethogram adapted from studies conducted by Lima et al. (2014) and Schiassi et al. (2015). The frequency and percentage of observation time in each behavior were determined in their respective treatments. For data analysis, the following were 
Table 1. Behavioral ethogram for broilers

\begin{tabular}{|c|c|}
\hline Behaviors & Description \\
\hline Standing & Behavior characterized when the bird rests on its feet. \\
\hline Lying & Behavior characterized when the bird's body is in contact with the ground, floor or bedding. \\
\hline Eating & Consuming or pecking feed from the feeder. \\
\hline Drinking & Consuming water from the drinker. \\
\hline Exploring feathers & Exploring plumage with the beak, for both maintenance and investigation. \\
\hline Non-aggressive pecking & Slightly pecking other birds, usually in the lower ventral region of the neck, back, base and tip of the tail or abdomen. \\
\hline Aggressive pecking & $\begin{array}{l}\text { Strongly pecking another bird, causing aggressive or defensive reaction, usually directed to the upper region of the head and } \\
\text { comb or in the lower dorsal region of the neck. }\end{array}$ \\
\hline Pecking objects & Pecking objects or parts of the pen, except for feeder and drinker. \\
\hline Comfort movements & $\begin{array}{l}\text { Movements of stretching the wings and legs on the same side of the body simultaneously, shaking and ruffling feathers, } \\
\text { lifting part of both wings near the body or extending the tips of the wingsand/or flapping wings. }\end{array}$ \\
\hline Foraging & When the bird explores its territory with its feet and beak, directed to the floor. \\
\hline Dust bathing & Rolling on the bedding substrate or soil in the pen area, spreading it across the body. \\
\hline Still & Behavior characterized when the bird has no movement, or apparently does not fit any of the previous behaviors. \\
\hline Discomfort movements & $\begin{array}{l}\text { Movements of aggressiveness; stretching the whole body to increase the area of contact with the bedding, open beak } \\
\text { (panting). }\end{array}$ \\
\hline
\end{tabular}

considered as natural behavior: foraging, dust bathing, nonaggressive pecking, pecking objects and feather exploration (Table 1).

The behavioral variables of the birds were determined by the frequency of the events and their probability of occurrence by the Chi-square $\left(\mathrm{X}^{2}\right)$ test.

\section{Results AND Discussion}

For the standing posture, birds exposed to $5 \mathrm{~lx}$ illuminance with blue/green color (I1C2) showed higher frequency, followed by birds subjected to $20 \mathrm{~lx}$ illuminance with blue/ green color (I2C2), equal to 530 and 498, respectively. The 5-20 lx illuminance with blue/green color (I4C2) caused the birds to spend less time standing, with a frequency of 374 . Thus, it is observed that the birds under I1C2 and I2C2 were more active (standing), and there was greater interest in searching for the feeder with observation frequency of the order of 341 and 354, respectively (Table 2).
The highest frequency of access of the birds to the drinker was observed in the treatment I1C2, while the lowest was found in I3C2, with values of 140 and 97, respectively (Table 2). Hence, it was found that broilers subjected to low illuminance (5 lx) had no difficulty in locating the drinker and the feeder inside the production pen; these behaviors are a particularly strong motivation in broilers, which are selected to develop rapidly (Senaratna et al., 2016).

However, Carvalho et al. (2013) show that when birds are subjected to uncomfortable environments, with high temperatures, the first effect observed in the animals is the reduction in food consumption and increase in water consumption. The broilers evaluated had lower incidence of negative behaviors (aggressiveness) when subjected to $5 \mathrm{~lx}$ illuminance and to the combination of 5-20 lx (Table 2).

Lying and still behaviors were the ones that most stood out in all treatments, with the highest frequency for lying (826) and being still (672) in birds exposed to the treatments I4C2 and $\mathrm{I} 4 \mathrm{C} 1$, respectively (Table 2). When lying down, the birds

Table 2. Frequency (Freq) and percentage (Perc, \%) of the time spent in the behavioral expression of broilers subjected to I1C1 treatments (5 lx/white), I1C2 (5 lx/blue/green), I2C1 (20 lx/white), I2C2 (20 lx/blue/green), I3C1 (150 lx/white), I3C2 (150 lx/ blue/green), I4C1 (5-20 lx/white) and I4C2 (5-20 lx/blue/green)

\begin{tabular}{|c|c|c|c|c|c|c|c|c|c|c|c|c|c|c|c|}
\hline \multirow{2}{*}{ Treatments } & & \multicolumn{13}{|c|}{ Behaviors } & \multirow{2}{*}{ Total } \\
\hline & & Std & $\overline{L y}$ & $\overline{\mathrm{Dr}}$ & $\overline{E a}$ & $\overline{\mathrm{DB}}$ & $\overline{P O b}$ & $\mathrm{AgP}$ & NagP & For & ExpF & ComfM & Stl & DiscomiM & \\
\hline \multirow{2}{*}{$11 C 1$} & Freq & 393 & 807 & 129 & 208 & 11 & 9 & 1 & 5 & 52 & 88 & 36 & 649 & 12 & 2400 \\
\hline & Perc & 2.05 & 4.2 & 0.67 & 1.08 & 0.06 & 0.05 & 0.01 & 0.03 & 0.27 & 0.46 & 0.19 & 3.38 & 0.06 & 12.5 \\
\hline \multirow{2}{*}{ I1C2 } & Freq & 530 & 670 & 140 & 341 & 8 & 4 & 0 & 4 & 36 & 75 & 38 & 551 & 3 & 2400 \\
\hline & Perc & 2.76 & 3.49 & 0.73 & 1.78 & 0.04 & 0.02 & 0 & 0.02 & 0.19 & 0.39 & 0.2 & 2.87 & 0.02 & 12.5 \\
\hline \multirow{2}{*}{$12 \mathrm{C} 1$} & Freq & 397 & 803 & 128 & 213 & 18 & 14 & 1 & 13 & 41 & 115 & 22 & 627 & 8 & 2400 \\
\hline & Perc & 2.07 & 4.18 & 0.67 & 1.11 & 0.09 & 0.07 & 0.01 & 0.07 & 0.21 & 0.6 & 0.11 & 3.27 & 0.04 & 12.5 \\
\hline \multirow{2}{*}{$12 \mathrm{C} 2$} & Freq & 498 & 702 & 115 & 354 & 10 & 15 & 1 & 3 & 36 & 100 & 29 & 534 & 3 & 2400 \\
\hline & Perc & 2.59 & 3.66 & 0.6 & 1.84 & 0.05 & 0.08 & 0.01 & 0.02 & 0.19 & 0.52 & 0.15 & 2.78 & 0.02 & 12.5 \\
\hline \multirow{2}{*}{$\mid 3 C 1$} & Freq & 392 & 808 & 120 & 210 & 9 & 2 & 2 & 3 & 60 & 89 & 31 & 665 & 9 & 2400 \\
\hline & Perc & 2.04 & 4.21 & 0.63 & 1.09 & 0.05 & 0.01 & 0.01 & 0.02 & 0.31 & 0.46 & 0.16 & 3.46 & 0.05 & 12.5 \\
\hline \multirow{2}{*}{$13 \mathrm{C} 2$} & Freq & 418 & 782 & 97 & 229 & 14 & 21 & 2 & 11 & 54 & 92 & 28 & 647 & 5 & 2400 \\
\hline & Perc & 2.18 & 4.07 & 0.51 & 1.19 & 0.07 & 0.11 & 0.01 & 0.06 & 0.28 & 0.48 & 0.15 & 3.37 & 0.03 & 12.5 \\
\hline \multirow{2}{*}{$14 C 1$} & Freq & 377 & 823 & 138 & 180 & 18 & 8 & 2 & 5 & 26 & 122 & 26 & 672 & 3 & 2400 \\
\hline & Perc & 1.96 & 4.29 & 0.72 & 0.94 & 0.09 & 0.04 & 0.01 & 0.03 & 0.14 & 0.64 & 0.14 & 3.5 & 0.02 & 12.5 \\
\hline \multirow{2}{*}{$14 C 2$} & Freq & 374 & 826 & 104 & 199 & 12 & 11 & 1 & 5 & 58 & 119 & 51 & 632 & 8 & 2400 \\
\hline & Perc & 1.95 & 4.3 & 0.54 & 1.04 & 0.06 & 0.06 & 0.01 & 0.03 & 0.3 & 0.62 & 0.27 & 3.29 & 0.04 & 12.5 \\
\hline \multirow{2}{*}{ Total } & Freq & 3379 & 6221 & 971 & 1934 & 100 & 84 & 10 & 49 & 363 & 800 & 261 & 4977 & 51 & 19200 \\
\hline & Perc & 17.6 & 32.4 & 5.06 & 10.07 & 0.52 & 0.44 & 0.05 & 0.26 & 1.89 & 4.17 & 1.36 & 25.92 & 0.27 & 100 \\
\hline \multicolumn{2}{|c|}{ Chi-square } & & & & & & $\mathrm{DF}$ & & & & & & & Probability & \\
\hline \multicolumn{2}{|c|}{387.3283} & & & & & & 84 & & & & & & & $p \leq 0.0001$ & \\
\hline
\end{tabular}

Behavioral activities expressed by broilers: Std - Standing; Ly - Lying; Dr - Drinking; Ea - Eating; DB - Dust bathing; POb - Pecking objects; AgP - Aggressive pecking; NagP - Nonaggressive pecking; For - Foraging; ExpF - Exploring feathers; ComfM - Comfort movement; Stl - Still; DiscomfM - Discomfort movement; DF - Degrees of freedom 
increase their contact with the bedding, which enables greater heat exchange with the environment through conduction (Carvalho et al., 2013). Lima et al. (2014) point out that the state of idleness (lying and standing) is related to the natural inactivity of broilers, when close to slaughter age, when they can spend up to $80 \%$ of their time at rest.

However, Carvalho et al. (2013) report that this behavior can be easily visualized when birds are under conditions of thermal stress, as there is a need to reduce their activity in environments with temperature above the upper critical temperature $\left(27^{\circ} \mathrm{C}\right)$. Birds employ this defense mechanism because less energy is spent when they are standing still.

It is observed that the expression of comfort and natural behaviors (dust bathing, object pecking, non-aggressive pecking, foraging, exploring feathers) in birds subjected to I2C1 and I3C1 had the highest (201) and lowest (163) total frequencies of observation, respectively, whereas birds subjected to I4C2 showed the highest frequency (205) and those exposed to I1C2 showed the lowest frequency (127). Comfort and natural behaviors of the birds are associated with thermoneutrality, namely: non-aggressive pecking, pecking objects, foraging, exploring feathers, dust bathing, comfort movements (Table 2).

Higher total frequency of discomfort movements and aggressive pecking was observed in birds subjected to white

A.

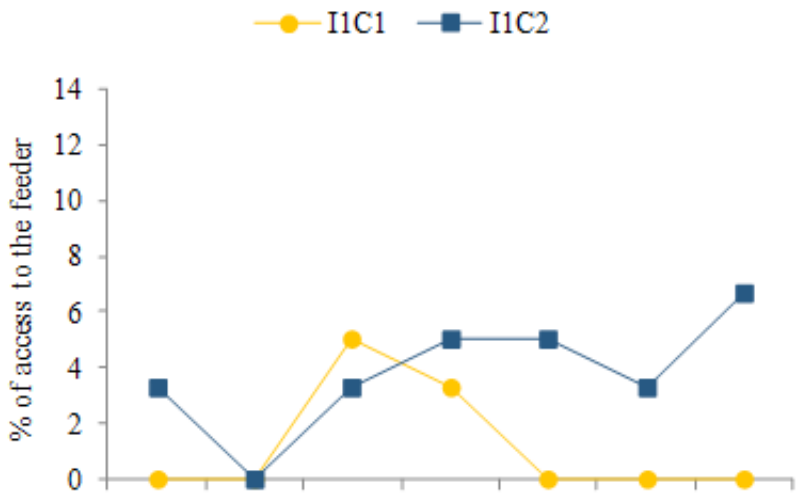

C.

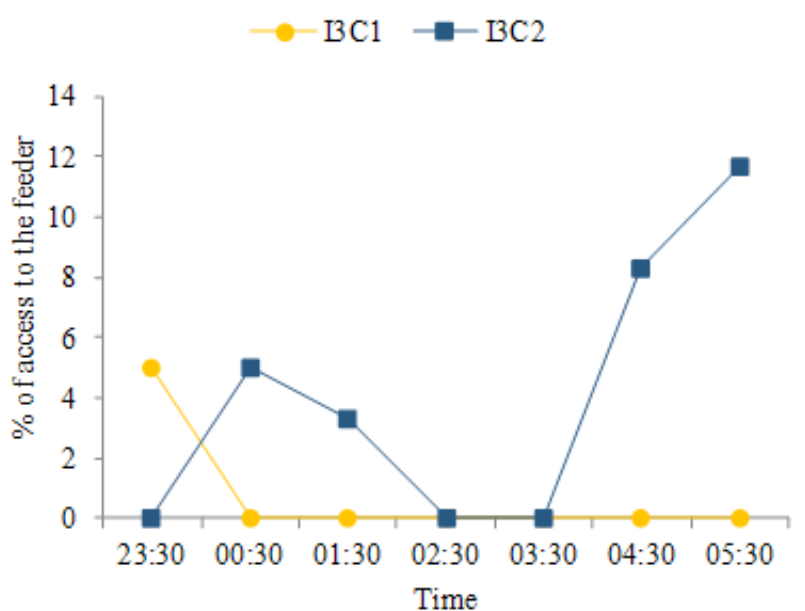

LED light (C1), with frequency of 38, while birds under blue/ green light (C2) showed frequency of 23 (Table 2). Similar results were found by Kim et al. (2014).

The welfare of the animal is affected when it cannot adapt to the housing environment and stress factors, and such incapacity to adapt can manifest through physiological and or behavioral changes. When the natural behavior of the animal is no longer expressed or when there are changes in its frequency, this may indicate that the welfare has been adversely altered (Senaratna et al., 2016).

Figure 1 shows the percentage of access to the feeder as a function of the daily housing hours. Animals exposed to I2C2 (Figure 1B) showed the best response, remaining at the feeder for $55 \%$ of the analyzed time. Among the birds subjected to white light, the ones that remained longer at the feeder were those subjected to I2C1 (Figure 1B), which spent $18 \%$ of the time at the feeder, corroborating Zhang et al. (2016).

In treatments with $5 \mathrm{~lx}$ (Figure 1A), $150 \mathrm{~lx}$ (Figure 1C) and 5-20 lx (Figure 1D), broilers subjected to blue/green LED lights had higher frequency of access to the feeder, respectively 27 , 28 and $28 \%$ more compared to birds under white LED $(8,5$ and $13 \%$ respectively).

In broilers, the appetitive phase can be characterized by the behavior of foraging, which is when the bird explores the area in search of food. In addition, ingestive behavior can be

B.

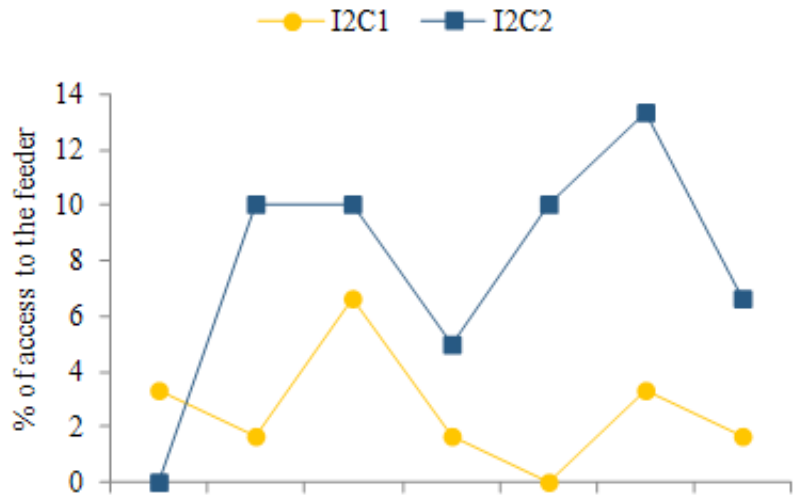

D.

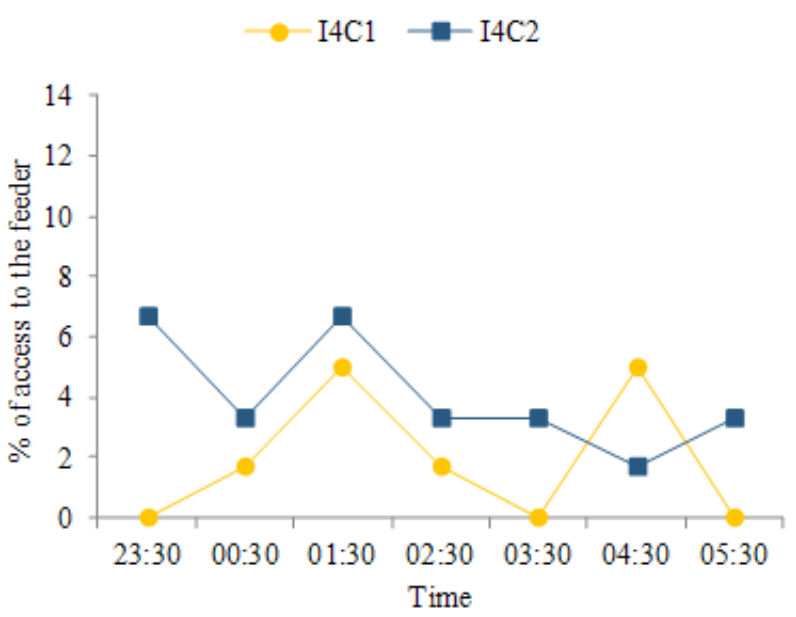

Figure 1. Percentage of access to the feeder by birds subjected to $5 \mathrm{~lx} /$ white (I1C1) and $5 \mathrm{~lx} / \mathrm{blue} / \mathrm{green}$ (I1C2) - A; 20 lx/white (I2C1) and $20 \mathrm{~lx} /$ blue/green (I2C2) - B; $150 \mathrm{~lx} /$ white (I3C1) and $150 \mathrm{~lx} /$ blue/green (I3C2) - C; and 5-20 lx/white (I4C1) and 5-20 lx/blue/green (I4C2) - D, as a function of time 
recorded as events of visits to feeders (Carvalho et al., 2013; Lima et al., 2014; Schiassi et al., 2015).

Figure 2 shows the percentage of time spent by birds at the drinker, as affected by the levels of illuminance and wavelengths studied. Birds subjected to I1C2 (Figure 2A) spent 15\% of the time analyzed at the drinker. For birds subjected to $\mathrm{I} 4 \mathrm{C} 1$ (Figure 2D), the access to the drinker totaled $12 \%$ of the time of actuation of the artificial lighting system.

In the treatments with $20 \mathrm{~lx}$ (Figure 2B) and $150 \mathrm{~lx}$ (Figure 2C), the broilers subjected to blue/green LED lights spent approximately 3 and $12 \%$, respectively, of the of time at the drinker, while birds under white LED remained 3\% in both treatments.

This result differs from that found by Deep et al. (2013), who observed that illuminance had no effect on the access to the drinker; however, it corroborates the studies conducted by Baltchford et al. (2012), who verified the influence of illuminance between 5 and $200 \mathrm{~lx}$ on the access to the drinker, as birds exposed to $5 \mathrm{~lx}$ remained drinking for a longer period.

The increase in water intake has the function of moderating body temperature and reducing the dehydration caused by heat loss through evaporation, due to increased respiratory rate (Navas et al., 2016). Under these conditions, the specific heat of the water helps in the thermolysis of the birds, in the face of the fluctuation observed in room temperature.

A.

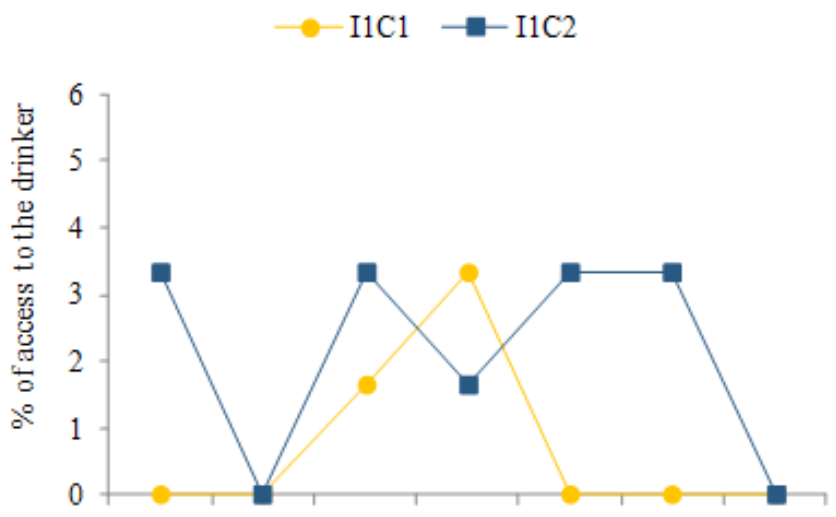

C.

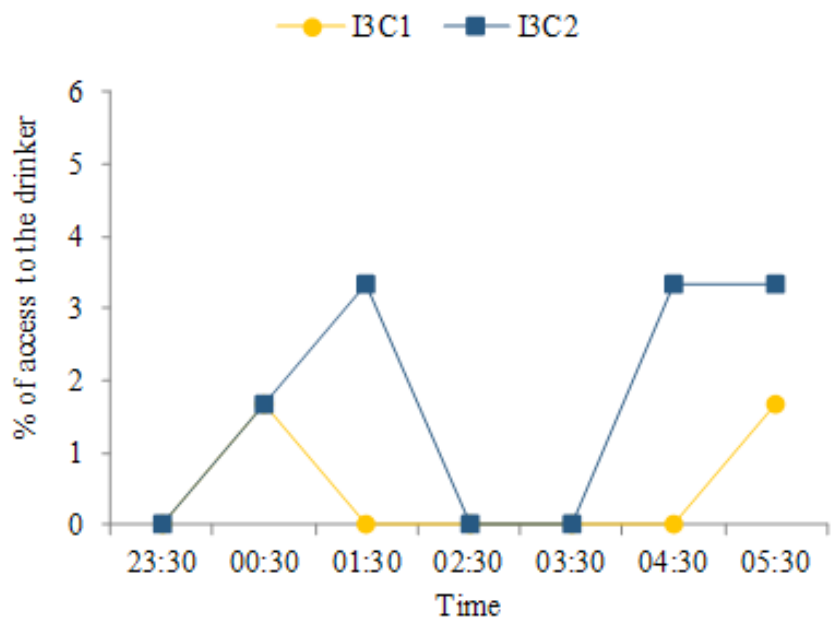

Figure 3 shows the percentage of time spent by the birds in comfort and natural movements. Among the treatments under lighting with blue/green LED, broilers in I1C2 (Figure $3 \mathrm{~A}$ ), I2C2 (Figure 3B), I3C2 (Figure 3C) and I4C2 (Figure $3 \mathrm{D})$ remained $28,10,23$ and $22 \%$, respectively, of the time performing comfort and natural movements. Birds exposed to I3C1 (Figure 3C) showed the highest expression under white LED, totaling $23 \%$ of the time in comfort movements. The treatments I1C1 (Figure 3A), I2C1 (Figure 3B) and I4C1 (Figure $3 \mathrm{D}$ ) led to 10,13 , and $12 \%$ of time spent in comfort and natural movements.

The behavioral results related to the blue/green light spectrum are corroborated by the study conducted by Kim et al. (2014), who show that broilers subjected to blue/green lighting are calmer and have higher frequency of comfort and natural movement behaviors, as well as better welfare.

Comfort behaviors are considered the most important ones in relation to animal welfare, because they are usually performed after all other basic needs have been met, so they are more subject to changes in frequency than ingestive behaviors, such as eating and drinking (Lima et al., 2014). They include dust bathing, exploring feathers, foraging, flapping wings, ruffling feathers, stretching, pecking objects and nonaggressive pecking (Kim et al., 2014).

B.

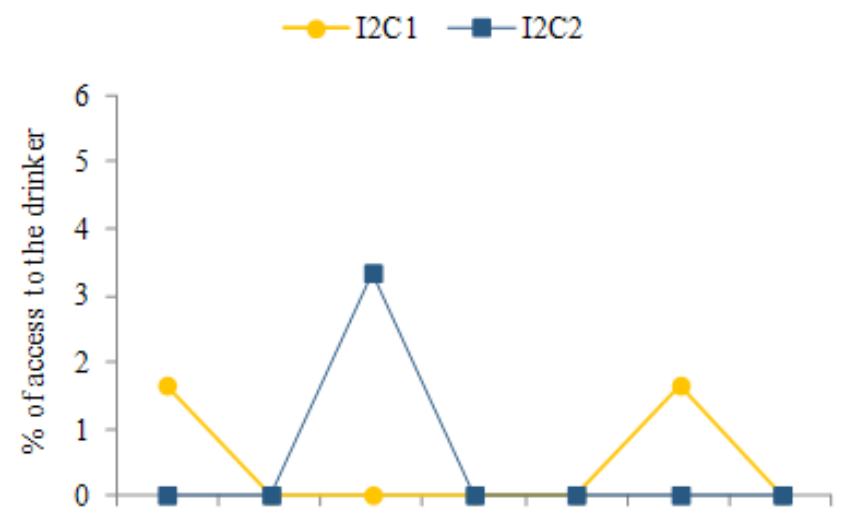

D.

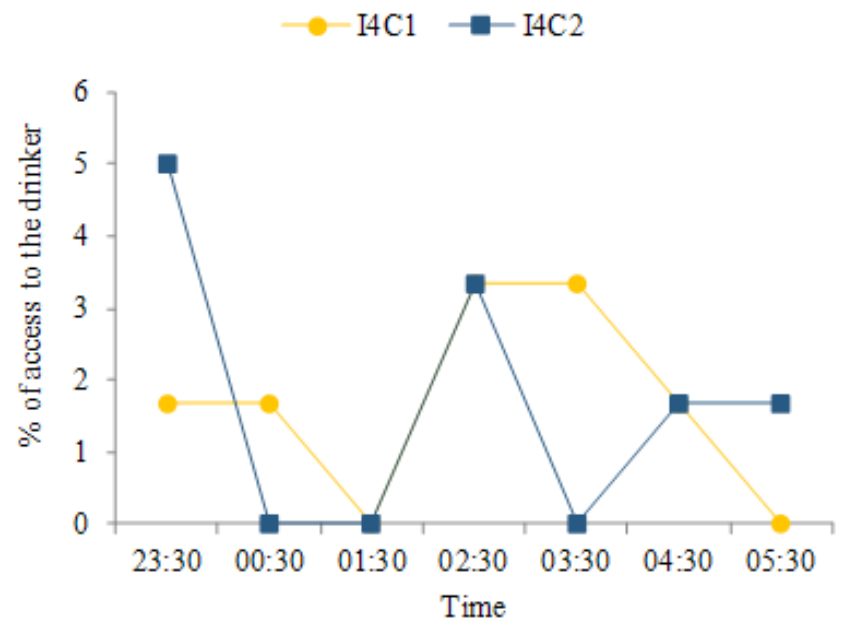

Figure 2. Percentage of access to the drinker by birds subjected to $5 \mathrm{~lx} /$ white (I1C1) and $5 \mathrm{~lx} / \mathrm{blue} / \mathrm{green}$ (I1C2) - A; $20 \mathrm{~lx} /$ white (I2C1) and $20 \mathrm{~lx} /$ blue/green (I2C2) - B; $150 \mathrm{~lx} /$ white (I3C1) and $150 \mathrm{~lx} /$ blue/green (I3C2) - C; 5-20 lx/white (I4C1) and 5-20 $\mathrm{lx} /$ blue/green (I4C2) - D, as a function of time 
A.

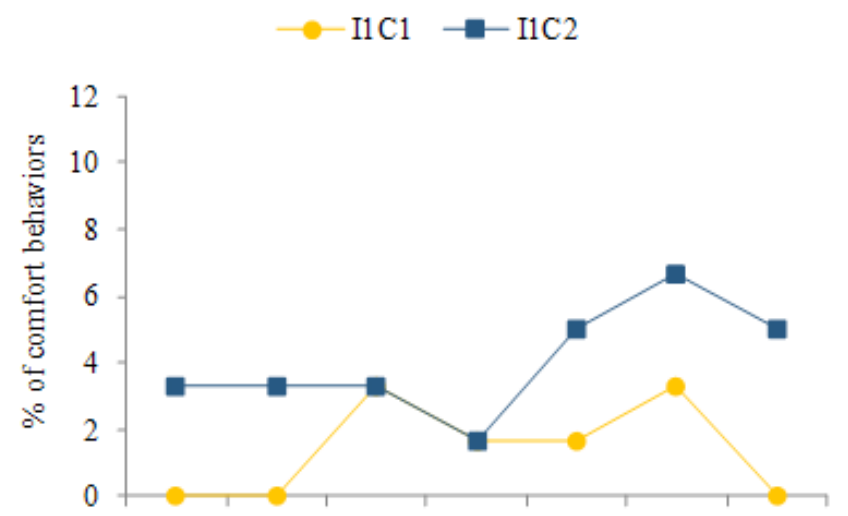

C.

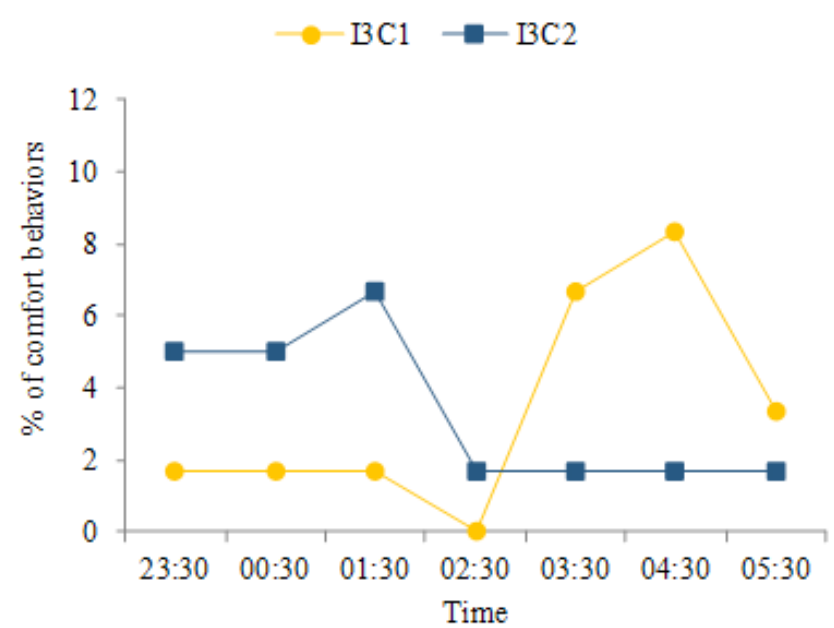

B.

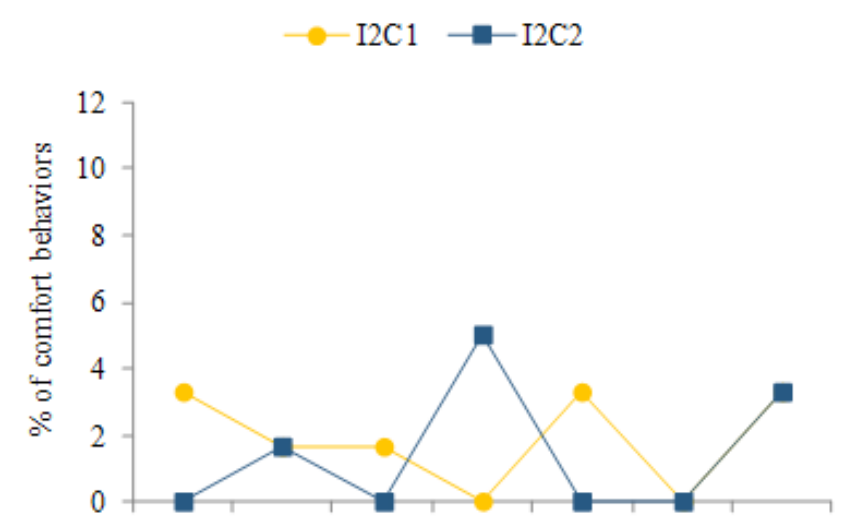

D.

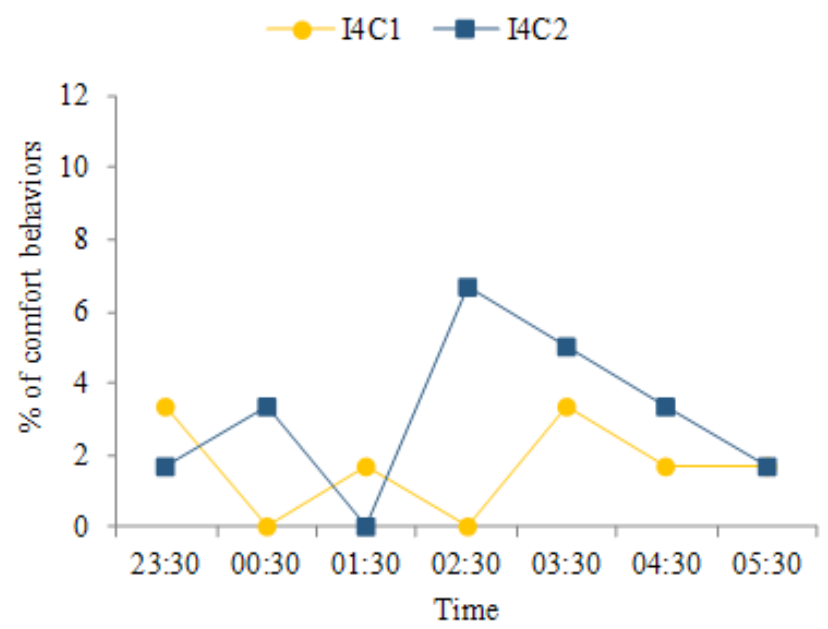

Figure 3. Percentage of expression of comfort and natural movement behaviors of birds subjected to $5 \mathrm{~lx} /$ white (I1C1) and $5 \mathrm{~lx} /$ blue/green (I1C2) - A; $20 \mathrm{~lx} /$ white (I2C1) and $20 \mathrm{~lx} /$ blue/green (I2C2) - B; $150 \mathrm{~lx} /$ white (I3C1) and 150 lx/blue/green (I3C2) - C; 5-20 lx/white (I4C1) and 5-20 lx/blue/green (I 4C2) - D, as a function of time

\section{Conclusions}

1. Birds subjected to wavelengths in the range of blue/green and illuminance of $20 \mathrm{~lx}$ and 5-20 lx had more significant ingestive and comfort behaviors, which demonstrates better welfare under these housing conditions.

2. Broilers subjected to wavelength in the white band had higher incidence of aggressive behavior and discomfort, which shows that birds exposed to blue and green light (short waves) remained calmer than those exposed to white light (long waves).

\section{ACKNOWLEDGMENTS}

The present study was carried out with support from the Coordenação de Aperfeiçoamento de Pessoal de Nível Superior - Brasil (CAPES) - Financing Code 001.

\section{Literature Cited}

Alvares, C. A.; Stape, J. L.; Sentelhas, P. C.; Gonçalves, J. L. M.; Sparovek, G. Köppen's climate classification map for Brazil. Meteorologische Zeitschrift, v.22, p.711-728, 2013. https://doi. org/10.1127/0941-2948/2013/0507
Blatchford, R. A.; Acher, G. S.; Mench, J. A. Contrast in light intensity, rather than day length, influences the behavior and health of broiler chickens. Poultry Science, v.91, p.1768-1774, 2012. https:// doi.org/10.3382/ps.2011-02051

Carvalho, G. B. de; Lopes, J. B.; Santos, N. P. S.; Reis, N. B. do N.; Carvalho, W. F. de; Silva, S. F. da; Carvalho, D. A. de; Silva, E. M. da; Silva, S. M. da. Comportamento de frangos de corte criados em condições de estresse térmico alimentados com dietas contendo diferentes níveis de selênio. Revista Brasileira de Saúde e Produção Animal, v.14, p.785-797, 2013. https://doi.org/10.1590/S1519-99402013000400012

Costa, L. S.; Pereira, D. F.; Bueno, L. G. F.; Pandorfi, H. Some aspects of chicken behavior and welfare. Brazilian Journal of Poultry Science, v.14, p.159-232, 2012. https://doi.org/10.1590/S1516-635X2012000300001

Deep, A.; Raginski, C.; Schwean-Lardner K.; Fancher, B. I.; Classena, H. L. Minimum light intensity threshold to prevent negative effects on broiler production and welfare. British Poultry Science, v.54, p.686-694, 2013. https://doi.org/10.1080/00071668.2013.847526

Kim, N.; Lee, S. R.; Lee, S. J. Effects of light color on energy expenditure and behavior in broiler chickens. Asian-Australasian Journal of Animal Sciences, v.27,p.1044-1049,2014. https://doi.org/10.5713/ajas.2012.12425 Lima, K. A. O.; Garcia, R. G.; Nääs, I. A.; Caldara, F. R.; Santana, M. R.; Royer, A. F. B; Castilho, V. A. R. Impacto da iluminação artificial no comportamento de frangos de corte. Revista Agrarian, v.7, p.301-309, 2014. 
Navas, T. de O.; Oliveira, H. F. de; Carvalho, F. B. de; Stringhini, J. H.; Café, M. B.; Hellmeister Filho, P. Estresse por calor na produção de frangos de corte. Revista Nutritime, v.13, p.4550-4557, 2016.

Olanrewaju, H. A.; Miller, W. W.; Maslin, W. R.; Collier, S. D.; Purswell, J. L.; Branton, S. L. Effects of strain and light intensity on growth performance and carcass characteristics of broilers grown to heavy weights. Poultry Science, v.93, p.1890-1899, 2014. https:// doi.org/10.3382/ps.2013-03806

Parvin, R.; Mushtaq, M. M. H.; Kim, M. J.; Choi, H.C. Light emitting diode (LED) as a source of monochromatic light: a novel lighting approach for behaviour, physiology and welfare of poultry. Worlds Poultry Science Journal, v.70, p.543-556, 2014. https:// doi.org/10.1017/S0043933914000592

Rault, J. L.; Clark, K.; Groves, P. J.; Cronin, G. M. Light intensity of 5 or 20 lux on broiler behavior, welfare and productivity. Poultry Science, v.96, p.779-787, 2017. https://doi.org/10.3382/ps/pew423

Schiassi, L.; Yanagi Junior, T.; Ferraz, P. F. P.; Campos, A. T.; Silva, G. R.; Abreu; L. H. P. Comportamento de frangos de corte submetidos a diferentes ambientes térmicos. Engenharia Agrícola, v.35, p.390-396, 2015. https://doi.org/10.1590/1809-4430-Eng.Agric. v35n3p390-396/2015
Senaratna, D.; Samarakone, T. S.; Gunawardena, W. W. D. A. Red color light at different intensities affects the performance, behavioral activities and welfare of broilers. Asian-Australasian Journal of Animal Sciences, v.29, p.1052-1059, 2016. https://doi.org/10.5713/ ajas. 15.0757

Sultana, S.; Hassan, M. R.; Choe, H. S.; Ryu, K. S. The effect of monochromatic and mixed LED light colour on the behaviour and fear responses of broiler chicken. Avian Biology Research, v. 6, p. 207-214, 2013. https://doi.org/10.3184/17581551 3X13739879772128

Vercellino, R. A.; Moura, D. J.; Nääs, I. A.; Maia, A. P.; Medeiros, B. B. B.; Salgado, D. D.; Carvalho, T. M. R. The influence of sidecurtain color in broiler chick behavior. Revista Brasileira de Ciência Avícola, v.15, p.173-179, 2013. https://doi.org/10.1590/ S1516-635X2013000300002

Zhang, L.; Zhu, X. D.; Wang, X. F.; Li, J. L.; Gao, F.; Zhou, G. H. GreenlLight-emitting diodes light stimuli during incubation enhances posthatch growth without disrupting normal eye development of broiler embryos and hatchlings. AsianAustralasian. Journal of Animal Sciences, v.29, p.1562-1568, 2016. https://doi.org/10.5713/ajas.15.0976 